\title{
Chronic Metabolic Acidosis Enhances NHE-3 Protein Abundance and Transport Activity in the Rat Thick Ascending Limb by Increasing NHE-3 mRNA
}

\author{
Kamel Laghmani, ${ }^{\star}$ Pascale Borensztein, ${ }^{\star}$ Patrice Ambühl,‡ Marc Froissart, ${ }^{\star}$ Maurice Bichara, ${ }^{\star}$ Orson W. Moe, ${ }^{\ddagger}$ \\ Robert J. Alpern, ${ }^{\ddagger}$ and Michel Paillard* \\ * Laboratoire de Physiologie et Endocrinologie Cellulaire Rénale, Institut National de la Santé et de la Recherche Médicale U. 356, \\ Université Pierre et Marie Curie, Centre Hospitalo-Universitaire Broussais, Paris, France; and ${ }^{\ddagger}$ Department of Internal Medicine, \\ University of Texas Southwestern Medical Center, Dallas, Texas
}

\begin{abstract}
Chronic metabolic acidosis (CMA) is associated with an adaptive increase in the bicarbonate absorptive capacity of the rat medullary thick ascending limb (MTAL). To specify whether NHE-3, the apical MTAL Na/H exchanger, is involved in this adaptation, NHE-3 mRNA was quantified by a competitive RT-PCR using an internal standard which differed from the wild-type NHE-3 mRNA by an 80-bp deletion. CMA increased NHE-3 mRNA from $0.025 \pm 0.003$ to $0.042 \pm 0.009 \mathrm{amol} / \mathrm{ng}$ total RNA $(P<0.005)$. NHE-3 transport activity was measured as the initial proton flux rate calculated from the $\mathrm{Na}$-dependent cell $\mathrm{pH}$ recovery of $\mathrm{Na}$ depleted acidified MTAL cells in the presence of $50 \mu \mathrm{M}$ HOE694 which specifically blocks NHE-1, the basolateral MTAL NHE isoform. CMA caused a $68 \%$ increase in NHE-3 transport activity $(P<\mathbf{0 . 0 0 1})$. In addition, CMA was associated with a $71 \%$ increase in NHE-3 protein abundance $(P<$ 0.05 ) as determined by Western blot analysis on MTAL membranes using a polyclonal antiserum directed against a cytoplasmic epitope of rat NHE-3. Thus, NHE-3 adapts to CMA in the rat MTAL via an increase in the mRNA transcript that enhances NHE-3 protein abundance and transport activity. (J. Clin. Invest. 1997. 99:24-30.) Key words: $\mathrm{Na} / \mathrm{H}$ exchange $\bullet \mathrm{NHE}-3 \cdot$ acidosis $\bullet$ kidney
\end{abstract}

\section{Introduction}

Metabolic acidosis is associated with a number of adaptive changes in renal tubules that contribute to increased urinary net acid excretion. Chronic acid loading produces a large increase in the bicarbonate absorptive capacity of the proximal tubule (1). This adaptation occurs via parallel increases in $V_{\max }$

Portions of this work were presented at the 27th and 28th Annual Meeting of the American Society of Nephrology, Orlando, FL, in October 1994 and San Diego, CA, in November 1995.

Address correspondence to P. Borensztein, Unité INSERM 356, Centre de Recherches Biomédicales des Cordeliers, 15 rue de l'Ecole de Médecine, 75270 Paris Cedex 06, France. Phone: 33-144413710; FAX: 33-144413717.

Received for publication 10 June 1996 and accepted in revised form 10 October 1996.

J. Clin. Invest.

(C) The American Society for Clinical Investigation, Inc. 0021-9738/97/01/0024/07 \$2.00

Volume 99, Number 1, January 1997, 24-30 of the apical $\mathrm{Na}^{+} / \mathrm{H}^{+}$antiporter (2-6) and vacuolar $\mathrm{H}^{+}$-ATPase (7), and basolateral $\mathrm{Na}^{+}: 3 \mathrm{HCO}_{3}^{-}$cotransporter $(2,3)$. Current evidence strongly suggests that NHE-3, which encodes an amiloride-resistant $\mathrm{Na}^{+} / \mathrm{H}^{+}$exchanger (NHE), ${ }^{1}$ is an apical isoform of the NHE family and plays a significant role in $\mathrm{NaHCO}_{3}$ and $\mathrm{NaCl}$ absorption in the proximal tubule (8-10). Studies performed in a cell line derived from proximal tubules of the opossum kidney, the OKP cells, showed that both amiloride-resistant $\mathrm{Na}^{+} / \mathrm{H}^{+}$exchange activity and NHE-3 mRNA adapt to acid incubation (11). Recent in vivo studies have shown that chronic metabolic acidosis (CMA) increases NHE-3 protein abundance in cortical brush border vesicles $(12,13)$. However, no change in cortical NHE-3 mRNA abundance was observed when assayed by Northern blot analysis (12). Thus, although NHE-3 is probably involved in the acidinduced apical antiport activation, the mechanisms of this adaptation, related to increased levels of mRNA or to posttranslational regulation, remain unclear.

CMA is also associated with an adaptive increase in bicarbonate absorptive capacity in the rat medullary thick ascending limb (MTAL) (14). Bicarbonate absorption is mediated mainly via an apical $\mathrm{Na}^{+} / \mathrm{H}^{+}$antiporter in MTALs from both control and acidotic rats (15-17). We have shown recently, in microdissected rat MTAL, that NHE-3 mRNA is strongly expressed and NHE-1 mRNA is also detected, whereas NHE-2 and NHE-4 mRNAs are not detected (18). Furthermore, recent data have demonstrated that NHE-1 and NHE-3 are localized to the basolateral and apical plasma membrane of MTAL cells, respectively $(9,19-21)$.

The purpose of this study was to determine whether NHE-3 is directly involved in the in vivo adaptation of the MTAL bicarbonate absorption observed during CMA, and which mechanisms are involved. Thus, we developed a very sensitive competitive reverse transcription-PCR (RT-PCR) which allowed us to quantify NHE-3 mRNA in MTAL cells freshly isolated from $\mathrm{NH}_{4} \mathrm{Cl}$-induced acidotic rats. NHE-3 transport activity and NHE-3 protein abundance were also determined in the same preparations. The results show for the first time, in MTAL tubular cells, that CMA increases the level of mRNA transcript for NHE-3, associated with an increase in abundance and functional activity of the protein.

\section{Methods}

Animal treatment. Experiments were performed on male SpragueDawley rats (200-300 grams body wt). The animals were allowed free

1. Abbreviations used in this paper: CMA, chronic metabolic acidosis; dNTP, deoxyribonucleotide; MTAL, medullary thick ascending limb; $\mathrm{NHE}, \mathrm{Na}^{+} / \mathrm{H}^{+}$exchanger; RT, reverse transcription. 
access to food and drinking solution up to the time of the experiments. In each series, a group of experimental animals was compared directly with controls that were obtained from the same shipment and studied during the same period of time. CMA was obtained as follows: rats with CMA drank $0.28 \mathrm{M} \mathrm{NH}_{4} \mathrm{Cl}$ for $6 \mathrm{~d}$; control rats drank distilled $\mathrm{H}_{2} \mathrm{O}$. Both groups received standard rat chow ad libitum.

On the day of the experiment, rats were anesthetized with pentobarbital sodium. In most animals, blood was collected by aortic puncture for analysis of plasma electrolytes and the kidneys were rapidly removed, weighed, and immersed into ice-cold Hanks' solution containing (mM): $137 \mathrm{NaCl} ; 5.4 \mathrm{KCl} ; 25 \mathrm{NaHCO}_{3}{ }^{-} ; 0.3 \mathrm{Na}_{2} \mathrm{HPO}_{4} ; 0.4$ $\mathrm{KH}_{2} \mathrm{PO}_{4} ; 0.5 \mathrm{MgCl}_{2} ; 10$ Hepes; 5 glucose; 1 leucine; and $1 \mathrm{mg} / \mathrm{ml} \mathrm{BSA.}$

Isolation of MTAL tubules. The method used has been described previously in detail $(17,22,23)$. Briefly, small tissue pieces of inner stripe of outer medulla were subjected at $37^{\circ} \mathrm{C}$ to successive 7 -min periods of collagenase digestion ( 0.75 grams/liter), which minimized the exposure time of the tubules to collagenase. The MTAL tubules were harvested by sieving the supernatants through a $75-\mu \mathrm{m}$ opening nylon mesh to separate MTAL fragments from isolated cells and small fragments of other medullary tissues and resuspended in an appropriate volume of the desired medium. The suspensions obtained from control and acidotic rats as observed by light microscopy were similarly composed almost exclusively of MTAL tubular fragments (>95\%).

Measurement of $\mathrm{pHi}$. MTAL cells were loaded with the $\mathrm{pH}$-sensitive probe $\mathrm{BCECF}$ by incubation for $15 \mathrm{~min}$ at $37^{\circ} \mathrm{C}$ in a $\mathrm{CO}_{2}$-free medium containing (mM): $140 \mathrm{Na} ; 3 \mathrm{KCl} ; 1 \mathrm{CaCl}_{2} ; 1 \mathrm{MgCl}_{2} ; 1 \mathrm{~K}_{2} \mathrm{HPO}_{4}$; 10 Hepes; 5 glucose; 1 leucine; $0.1 \mathrm{mg} / \mathrm{ml} \mathrm{BSA,} \mathrm{pH} \mathrm{7.4,} \mathrm{bubbled} \mathrm{with}$ $100 \% \mathrm{O}_{2}$ and containing $5 \mu \mathrm{M}$ BCECF acetoxymethyl ester (AM; dissolved in DMSO and stored at $-20^{\circ} \mathrm{C}$ ). The BCECF-loaded tubules were then washed by gentle centrifugation to remove the extracellular dye and resuspended in the same medium. Just before each run, aliquots of the MTAL tubules were sodium depleted and acidified by three washings and gentle centrifugations in $\mathrm{CO}_{2}$-free and sodium-free medium containing $(\mathrm{mM}): 140 \mathrm{~N}$-methyl-D-glucamine chloride (NMDG-Cl); $3 \mathrm{KCl} ; 1 \mathrm{CaCl}_{2} ; 1 \mathrm{MgCl}_{2} ; 1 \mathrm{~K}_{2} \mathrm{HPO}_{4} ; 10$ Hepes; 5 glucose; 1 leucine; $0.1 \mathrm{mg} / \mathrm{ml} \mathrm{BSA,} \mathrm{pH} \mathrm{7.4.} \mathrm{The} \mathrm{MTAL} \mathrm{cells} \mathrm{were}$ then diluted into cuvettes containing $2 \mathrm{ml}$ of the experimental medium to reach a final cytocrit of $\sim 0.1 \mathrm{vol} \%$. BCECF fluorescence was monitored by use of a spectrofluorometer (RF-5000; Shimadzu Corp., Tokyo, Japan) equipped with water-jacketed temperaturecontrolled cuvette holder and magnetic stirrer. Fluorescence intensity was recorded at one emission wavelength, $530 \mathrm{~nm}$, whereas the excitation wavelengths alternated automatically at 2-s intervals between two wavelengths, 500 and $450 \mathrm{~nm}$. The values of the 500-450-nm fluorescence ratio were converted into $\mathrm{pHi}$ values with use of calibration curves that were established after each experimental run: cells were permeabilized with Triton X-100 (0.025 g\%), and the relationship between extracellular BCECF fluorescence and medium $\mathrm{pH}$ was established.

Calculations of $\mathrm{H}^{+}$fluxes. To quantitate $\mathrm{Na}^{+} / \mathrm{H}^{+}$exchange activity, proton flux rates $\left(\mathrm{J}_{H}{ }^{+}, \mathrm{pmol} / \mathrm{min} / \mathrm{mm}\right.$ of tubule length) were calculated as $J_{H}{ }^{+}=d p H i / d t \times \beta i \times V$, where $\mathrm{dpHi} / \mathrm{dt}$ is the sodium-dependent initial rate of $\mathrm{pHi}$ recovery $(\mathrm{pH}$ units $/ \mathrm{min}), \beta \mathrm{i}$ is intrinsic intracellular buffering power ( $\mathrm{mmol} /$ liter $\cdot \mathrm{pH}$ unit), and $\mathrm{V}$ is cell volume (nl/mm tubule length).

To initiate a sodium-dependent $\mathrm{pHi}$ recovery, sodium-depleted acidified MTAL cells were abruptly added into an isosmotic $\mathrm{CO}_{2}$-free medium containing $30 \mathrm{mM} \mathrm{Na}(30 \mathrm{mM}$ NMDG-Cl replaced with 30 $\mathrm{mM} \mathrm{NaCl}$ ). The first $10 \mathrm{~s}$ of time course of this sodium-dependent pHi recovery was fitted to a linear equation to calculate the initial rate of change of $\mathrm{pHi}(\mathrm{dpHi} / \mathrm{dt})$; correlation coefficients for these linear fits were $>0.96$.

$\beta i$ was determined from immediate alkalinization of sodiumdepleted acidified MTAL cells caused by addition of $15 \mathrm{mM} \mathrm{NH}_{4} \mathrm{Cl}$ in the Na-free medium containing $10 \mathrm{mM}$ barium and $0.5 \mathrm{mM}$ amiloride to block $\mathrm{NH}_{4}{ }^{+}$MTAL carriers as previously described $(23,24)$.

Cell volume was determined by measuring tubule diameters under light microscopy as described $(25,26)$.
RNA extraction, $R T$, and PCR. Total RNA was extracted from MTAL cells using the method of Chomczynski and Sacchi as previously described (27) and quantified by the measure of its optical density at $260 \mathrm{~nm}$.

Primers used in this study for cDNA synthesis and PCR amplification were chosen from the published rat NHE-3 cDNA sequences (28) and are located near the $3^{\prime}$ end of the coding region, where there are low sequence homologies between the four isoforms. cDNA was synthesized from RNA samples with $200 \mathrm{U}$ Moloney murine leukemia virus reverse transcriptase (MMLV), 20 pmol of downstream primer, $4 \mu \mathrm{g}$ of yeast transfer RNA, $2.5 \mathrm{mM}$ each deoxyribonucleotide (dNTP), $10 \mathrm{mM}$ DTT, $2 \mathrm{U}$ of RNase inhibitor in $22 \mu \mathrm{l}$ reaction buffer containing $50 \mathrm{mM}$ Tris- $\mathrm{HCl}, 75 \mathrm{mM} \mathrm{KCl}$, and $3 \mathrm{mM} \mathrm{MgCl}_{2}$ at $37^{\circ} \mathrm{C}$ for $60 \mathrm{~min}$. Each reaction was performed in parallel with an otherwise identical one that contained no reverse transcriptase.

For PCR, $10 \mu \mathrm{l}$ of the cDNA solution was supplemented with $5 \mu \mathrm{l}$ of $10 \times$ PCR buffer, $5 \mu \mathrm{l}$ of a $25 \mathrm{mM} \mathrm{MgCl}_{2}$ solution, $10 \mathrm{pmol}$ of each primer, $1 \mu \mathrm{l}$ of a $25 \mathrm{mM} \mathrm{dNTP}$ solution, and $1.25 \mathrm{U}$ Taq polymerase in a final volume of $50 \mu \mathrm{l}$. Samples were overlayered with mineral oil, denatured at $94^{\circ} \mathrm{C}$ for 4 min followed by 30 cycles consisting of denaturing at $94^{\circ} \mathrm{C}(1 \mathrm{~min})$, annealing at $60^{\circ} \mathrm{C}(1 \mathrm{~min})$, and extension at $72^{\circ} \mathrm{C}(1.5 \mathrm{~min})$. PCR was completed by a final extension step of 10 min at $72^{\circ} \mathrm{C}$. The PCR products were size fractionated on $1.5 \%$ agarose gels stained with ethidium bromide.

Internal standard preparation and in vitro transcription. $500 \mathrm{ng}$ of total RNA extracted from MTAL suspension was submitted to RTPCR using the following primers corresponding to bases 1,073-1,103 and 2,466-2,486 of the NHE-3 coding region giving a fragment of 1,414 bp. The sequences of the primers were: 5'-CCACCACCGTGCGCTACACTA-3' (sense) and 5'-GAGTCAGGCGGCGGAAGTTGC-3' (antisense). A third oligonucleotide which was used as an amplification product-specific probe encompassed bases 2,052-2,082. The sequence of this oligonucleotide probe was 5'-GCCGACTTAAAGGACTCCAGGCGCTTCCG-3'.

The PCR product was analyzed by agarose gel electrophoresis, recovered from gel with Geneclean (Bio 101, La Jolla, CA), phosphorylated with $\mathrm{T} 4$ polynucleotide kinase, and the ends were filled in with T4 DNA polymerase.

The NHE-3 fragment $(1,414 \mathrm{bp})$ was then subcloned into the EcoRV site of linearized pBluescript (BSKS+) (Stratagene Inc., La Jolla, CA). To further characterize the DNA template, digestions by a set of restriction enzymes followed by Southern blot analysis using a ${ }^{32} \mathrm{P}$-labeled oligonucleotide probe specific for NHE-3 cDNA was performed and gave products of the expected size (data not shown). Subsequently, NHE-3 DNA plasmid was submitted to digestions with Bpu1101I and BspMI restriction enzymes (bp 2,082 and bp 2,160 of the NHE-3 cDNA sequence, respectively), blunt-ended, and ligated, resulting in a 80-bp deletion of the 1,414-bp NHE-3 DNA insert.

Sense RNA was transcribed from $4 \mu \mathrm{g}$ of EcoRI-cut DNA template using an RNA transcription kit (Stratagene Inc.). Briefly, transcription was performed in a $100-\mu \mathrm{l}$ reaction volume containing 40 $\mathrm{mM}$ Tris ( $\mathrm{pH} 7.5$ ), $8 \mathrm{mM} \mathrm{MgCl}_{2}, 2 \mathrm{mM}$ spermidine, $50 \mathrm{mM} \mathrm{NaCl}, 0.4$ mM rUTP, $0.4 \mathrm{mM}$ rCTP, $0.4 \mathrm{mM}$ rATP, $0.16 \mathrm{mM}$ rGTP, $0.03 \mathrm{mM}$ DTT, $0.3 \mathrm{mM}$ cap analogue $\left(5^{\prime} 7 \mathrm{meGppp}^{\prime} \mathrm{G}\right), 10 \mu \mathrm{Ci}$ of [ $\left.{ }^{32} \mathrm{P}\right] \mathrm{UTP}$, and $40 \mathrm{U}$ of T3 RNA polymerase as appropriate. Incubation was carried out at $37^{\circ} \mathrm{C}$ for $30 \mathrm{~min}$. DNA template was then digested at $37^{\circ} \mathrm{C}$ for 10 min with $40 \mathrm{U}$ of RNase-free DNase. The mixture was then extracted with phenol-chloroform-isoamyl alcohol, precipitated with ethanol, and the pellet was resuspended in sterile water. The amount of cRNA synthesized was determined by the measure of its optical density at $260 \mathrm{~nm}$ and by liquid scintillation counting of the TCA-precipitated RNAs.

Quantification of NHE-3 $m R N A$. NHE-3 mRNA abundance was quantified by a competitive RT-PCR method, using the internal standard of cRNA which differed from the wild-type NHE-3 mRNA by an 80-bp deletion. Both cRNA and wild-type NHE-3 mRNA were reverse transcribed and amplified using primers $5^{\prime}$-GGAACAGAGGCGGAGGAGCAT-3' (sense, bp 1,885-2,085) and 5'-GAAGT- 
TGTGTGCCAGATTCT-3' (antisense, bp 2,186-2,206). These NHE-3 primers yielded a product of 321 bases (18) and 241 bases for wildtype and cRNA, respectively.

For each determination, seven to eight competitive RT-PCR reaction points were performed and resolved on $1.5 \%$ agarose gels stained with ethidium bromide. As illustrated in Fig. $1 A$, addition of decreasing amounts, from 168 to 0.84 amol, of the competitive template to replicate reactions containing identical amounts of MTAL total RNA resulted in a progressive decrease of the competitive template PCR product (241 bp) and a corresponding progressive increase of the wild-type template PCR product ( $321 \mathrm{bp}$ ). Photography of the gel was numerized and quantification of the fluorescence intensity of each PCR product, which is proportional to the amount of DNA, was performed on NIH Image 1.51. NHE-3 mRNA abundance was calculated as follows (Fig. $1 \mathrm{~B}$ ): a log-log scale plot of the ratio of fluorescence intensity of the wild-type to competitive PCR products versus the known amount of cRNA added in the replicate reaction yielded a linear plot. To correct for differences in molecular weight, fluorescence data obtained from competitive template were multiplied by 321/241. At the point where wild-type and competitive PCR products are in equivalence [i.e., $\log ($ ratio $)=1$ ], the amount of wild-type (NHE-3 mRNA) present in the initial sample is equal to the known starting amount of competitive template. Results are expressed in attomoles of NHE-3 mRNA per nanogram of total RNA.

A

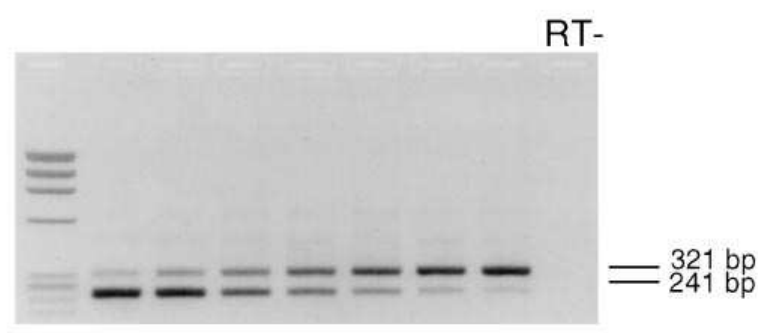

B

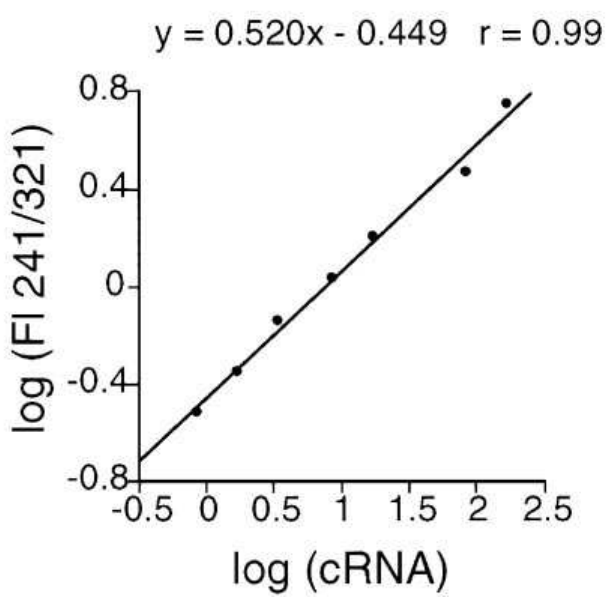

Figure 1. Quantification of MTAL NHE-3 mRNA by competitive RT-PCR. (A) Ethidium bromide-stained gel for competitive RTPCR analysis of 288 ng MTAL total RNA. The amount of cRNA added in each reaction was $168,84,17,8.4,3.4,1.68,0.84$ amol, respectively, resulting in a progressive competition between PCR products derived from wild-type NHE-3 mRNA (upper band, $321 \mathrm{bp}$ ) and from cRNA (lower band, $241 \mathrm{bp}$ ). RT-, reaction performed in the absence of reverse transcriptase (to rule out contaminating DNA). (B) Log-log plot of the ratio of quantitative fluorescence data versus initial amount of cRNA (attomoles).
Dot-blot analysis. Serial dilutions from 130 to $12.5 \mathrm{ng}$ of MTAL total RNA were denatured in $2.2 \mathrm{M}$ formaldehyde, $15 \times$ SSC $(1 \times$ SSC is $0.15 \mathrm{M} \mathrm{NaCl}$ and 0.015 sodium citrate, $\mathrm{pH} 7.0$ ) and dot-blotted onto Biodyne nylon membranes using a commercial vacuum-driven dotblot (GIBCO-BRL, Gaithersburg, MD) apparatus and fixed by ultraviolet cross-linking. Filters were prehybridized in $4 \times$ SSC, $50 \mathrm{mM}$ $\mathrm{NaPO}_{4}, 1 \times$ Denhardt's solution for $2 \mathrm{~h}$ at $42^{\circ} \mathrm{C}$, hybridized in the same solution containing $25 \times 10^{6} \mathrm{cpm}$ of ${ }^{32} \mathrm{P}$-radiolabeled oligo-dT at $42^{\circ} \mathrm{C}$ overnight, and washed once in $2 \times$ SSC with $0.1 \%$ SDS at room temperature for $10 \mathrm{~min}$, and twice in the same solution at $37^{\circ} \mathrm{C}$ for 20 min. Filters were exposed to film for $1 \mathrm{~h}$ at $-80^{\circ} \mathrm{C}$, and labeling was quantified by densitometry.

Preparation of MTAL membranes and detection of NHE-3 protein abundance by Western blot analysis. MTAL tubule suspensions were homogenized in membrane buffer $(150 \mathrm{mM} \mathrm{NaCl}, 50 \mathrm{mM}$ Tris$\mathrm{HCl}, 5 \mathrm{mM}$ EDTA containing in $\mu \mathrm{g} / \mathrm{ml}$ : 50 AEBSF, 2 leupeptin, 2 aprotinin) and centrifuged at $10,000 \mathrm{~g}$ for $15 \mathrm{~min}$ at $4^{\circ} \mathrm{C}$. The supernatant was then centrifuged at $100,000 \mathrm{~g}$ for $20 \mathrm{~min}$ (Optima TLX Ultracentrifuge; Beckman Instruments Inc., Fullerton, CA). Pellets were resuspended in membrane buffer and protein content was assessed by Bradford assay. $30 \mu \mathrm{g}$ of protein was diluted 1:5 in 5× SDS loading buffer (5 mM Tris $\mathrm{HCl}$, pH 6.8, 1\% SDS, $10 \%$ glycerol, $1 \%$ 2-mercaptoethanol), boiled for $10 \mathrm{~min}$, size fractionated by SDS-PAGE on $7.5 \%$ gels, and electrophoretically transferred to nitrocellulose. After transfer, equal loading of the lanes was controlled first by Ponceau red staining of the lower third of the membrane (which was cut off), and second by Coomassie blue staining of the remaining membrane. In all cases, protein loading of the lanes was equal between control and experimental groups. After blocking with 5\% nonfat milk and $0.05 \%$ Tween 20 in PBS for $1 \mathrm{~h}$, blots were probed in the same buffer for $1 \mathrm{~h}$ with a polyclonal anti-rat NHE-3 antibody directed against amino acids 809-822 of the COOH-terminal cytoplasmic domain of rat NHE-3 (antiserum 1568) (9), at a dilution of 1:100. Blots were washed in $1 \%$ Tween 20 in PBS for $15 \mathrm{~min}$ once, and for $5 \mathrm{~min}$ twice, incubated with a 1:10,000 dilution of peroxidase-labeled sheep antirabbit $\mathrm{IgG}$ in $5 \%$ nonfat milk and $0.025 \%$ Tween 20 in PBS for $1 \mathrm{~h}$, washed as above, and then visualized by enhanced chemiluminescence (Amersham Corp., Arlington Heights, IL). NHE-3 protein abundance was quantified by densitometry.

Statistics. Results were expressed as mean \pm SEM. Differences between means were evaluated using the paired or unpaired $t$ test as appropriate. $P<0.05$ was considered statistically significant.

Materials. Collagenase $\mathrm{CH}$ grade was obtained from Boehringer Mannheim France (Meylan, France), BCECF-AM was from Molecular Probes (Eugene, OR). NMG-Cl, amiloride, bumetanide, DMSO, and all chemicals were obtained from Sigma-Chimie (La Verpillère, France). Guanidium thiocyanate, phenol, Taq polymerase, RNase inhibitor, MMLV reverse transcriptase, and restriction enzymes were obtained from GIBCO-BRL. $\left[{ }^{32} \mathrm{P}\right] \gamma \mathrm{ATP}$ was obtained from Amersham. dNTP and yeast tRNA were obtained from Stratagene.

\section{Results}

Systemic measurements made at the end of the treatment period are shown in Table I. Animals tolerated each of the treatment regimens well, and all animals gained weight throughout the treatment period. Final body weight was significantly lower in the acidosis group. As expected, plasma $\mathrm{pH}$ and bicarbonate concentration was significantly reduced in the $\mathrm{NH}_{4} \mathrm{Cl}$ treated rats.

Quantification of NHE-3 $m R N A$ in MTAL cells. In the inner stripe of the outer medulla, NHE-3 is exclusively expressed in the TAL $(9,29)$, which allowed us to quantify NHE-3 mRNA by a very sensitive quantitative RT-PCR method from small amounts of MTAL suspension. 
Table I. Body Weight, Kidney Weight, and Plasma Electrolytes

\begin{tabular}{cccccccccc}
\hline & Initial body wt & Final body wt & Kidney wt & $\mathrm{pH}$ & $\mathrm{pCO}_{2}$ & $\mathrm{HCO}_{3}^{-}$ & $\mathrm{Na}^{+}$ & $\mathrm{K}^{+}$ \\
\hline \multirow{4}{*}{ Control } & grams & grams & grams & $p H$ units & $m m H g$ & $m M$ & $m M$ & $m M$ \\
& $279 \pm 5$ & $336 \pm 5$ & $1.23 \pm 0.04$ & $7.42 \pm 0.01$ & $37.3 \pm 0.7$ & $23.9 \pm 0.4$ & $142.6 \pm 0.34$ & $4.4 \pm 0.1$ \\
Acidosis & $(20)$ & $(20)$ & $(7)$ & $(20)$ & $(20)$ & $(20)$ & $(11)$ & $(11)$ \\
& $278 \pm 5$ & $304 \pm 5^{*}$ & $1.23 \pm 0.02$ & $7.31 \pm 0.01^{*}$ & $33.8 \pm 0.5^{*}$ & $17.1 \pm 0.3^{*}$ & $144.3 \pm 0.4^{*}$ & $3.9 \pm 0.1^{*}$ \\
& $(20)$ & $(20)$ & $(7)$ & $(20)$ & $(20)$ & $(20)$ & $(11)$ & $(11)$ \\
\hline
\end{tabular}

Values are means \pm SEM for the number of rats given in parentheses. ${ }^{*} P<0.05$ acidosis vs. control (unpaired $t$ test).

To test the efficiency and the reproducibility of NHE-3 mRNA quantification, we performed different competitive RT-PCR reactions as described in Methods with increasing amounts of MTAL total RNA extracted from three different preparations of MTAL tubules. As shown in Fig. 2, an excellent linearity was obtained when NHE-3 mRNA was plotted against the amount of initial MTAL total RNA (from 100 to $600 \mathrm{ng}$ ). These results show that the competitive RT-PCR reaction, performed from a fixed amount of MTAL total RNA enclosed in the linear range obtained above, can therefore estimate the MTAL NHE-3 mRNA abundance in optimal conditions.

Effect of CMA on NHE-3 $m R N A$. For each experiment, experimental and control rats were studied in parallel. The effect of CMA on the MTAL NHE-3 mRNA abundance is shown in Fig. 3. Results showed a $69 \%$ increase in the NHE-3 mRNA abundance in acidotic versus control groups $(0.0418 \pm 0.0091$ vs. $0.0248 \pm 0.003 \mathrm{amol} / \mathrm{ng}$ total RNA, $n=7, P<0.005)$. To appreciate the specificity of the acidosis-induced increase in NHE-3 mRNA, we quantified the amount of mRNAs present in MTAL total RNA samples by dot-blot analysis using radiolabeled oligo-dT as described in Methods. Serial dilutions of the same initial sample resulted in an equivalent decrease of labeling (Fig. 4). Results showed that, for a fixed amount of total RNA, the amount of mRNAs was not significantly affected by CMA ( $242 \pm 43$ vs. $288 \pm 40$ integrated OD units in acidosis, $n=7$, NS). Thus, the increase in NHE-3 mRNA abundance observed during CMA cannot be explained by a global increase of mRNAs. The next step of this study was to determine the effects of CMA on NHE-3 transport activity and protein abundance.

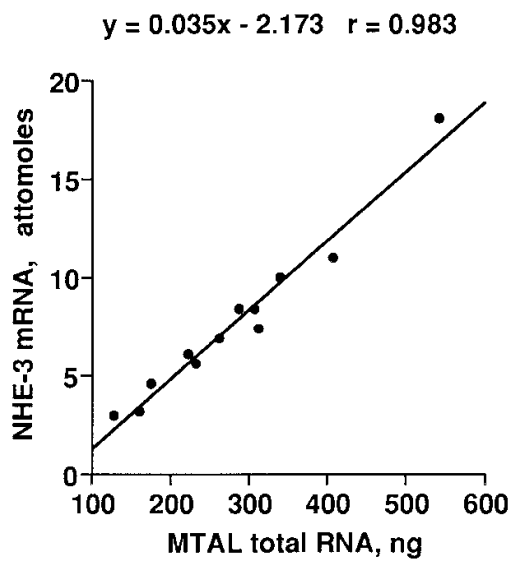

Figure 2. Separate competitive RT-PCR were performed as described in Methods, using varying amounts of MTAL total RNA ranging from 100 to $550 \mathrm{ng}$. Plot of NHE-3 mRNA abundance versus MTAL total RNA illustrates an excellent linearity over the MTAL total RNA range tested.
Effect of CMA on NHE-3 transport activity. For each experiment, measurements of intracellular buffering power ( $\beta i$ ), cell volume, and $\mathrm{Na}$-dependent $\mathrm{pHi}$ recovery $(\mathrm{dpHi} / \mathrm{dt})$ were performed on the same MTAL tubule suspension of control and experimental rats. $\beta i$ was not different in the acidosis versus control rats $\left(41.3 \pm 2.9\right.$ vs. $46.4 \pm 5.7 \mathrm{mmol} \mathrm{H}{ }^{+} /$liter $/ \mathrm{pH}$ unit, $n=5$, NS) whereas the cell volume was significantly increased in the acidosis versus control group $(0.65 \pm 0.07$ vs. $0.43 \pm 0.02$ $\mathrm{nl} / \mathrm{mm}$ tubule length, $n=5, P<0.05)$. To specifically study NHE-3 transport activity, NHE-1 activity was inhibited by 50 $\mu \mathrm{M}$ HOE 694, a compound that blocks NHE-1 4,000 times more potently than NHE-3 (30); we have shown previously (31) that global NHE activity in the MTAL reached a maximum plateau inhibition of $\sim 35 \%$ with $4-100 \mu \mathrm{M}$ HOE 694 ; $0.1 \mathrm{mM}$ bumetanide and $1 \mu \mathrm{M}$ amiloride (that had per se no significant effect on NHE-3 activity) were also present to block $\mathrm{Na}-\mathrm{K}-2 \mathrm{Cl}$ cotransport and possible $\mathrm{Na}$ conductance, respectively, that might be altered by acidosis (23). CMA induced a significant increase in the dpHi/dt $(0.985 \pm 0.072$ vs. $0.773 \pm$ $0.039 \mathrm{pH}$ unit $/ \mathrm{min}, n=5, P<0.05$ ) (Fig. $5 A$ ), whereas initial acidification $\mathrm{pHi}$ values were not different between the two groups ( $6.86 \pm 0.04$ vs. $6.89 \pm 0.03$, acidosis vs. control, $n=5$, NS). $\mathrm{Na}^{+}$-dependent proton flux rates $\left(J_{\mathrm{H}}+\right)$, calculated as described in Methods, were significantly increased by $68 \%$ in the acidosis versus control group ( $25.9 \pm 1.9$ vs. $15.4 \pm 0.4 \mathrm{pmol} / \mathrm{min} /$ $\mathrm{mm}, n=5, P<0.001$ ) (Fig. $5 B$ ). In the presence of $1 \mathrm{mM}$ amiloride, the $\mathrm{Na}^{+}$-dependent pHi recovery was suppressed and $J_{\mathrm{H}}+$ was abolished in both control and acidotic conditions $(1.9 \pm 2.1$ vs. $2.0 \pm 3.1 \mathrm{pmol} / \mathrm{min} / \mathrm{mm}$, control versus acidosis, $n=3$ ), which demonstrates that, in the presence of $50 \mu \mathrm{M}$ HOE 694 , the $\mathrm{Na}^{+}$-dependent $J_{\mathrm{H}}+$ was due to NHE-3 activity.

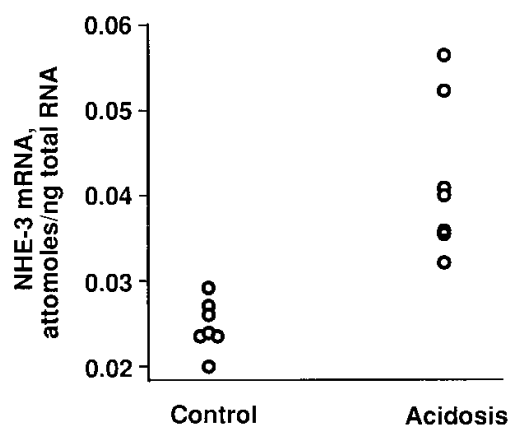

Figure 3. Effect of CMA on MTAL NHE-3 mRNA abundance. NHE-3 mRNA abundance was determined by competitive RT-PCR as described in Methods. Open circles are values for independent experiments. NHE-3 mRNA abundances were $0.0025 \pm 0.001$ vs.

$0.0042 \pm 0.003 \mathrm{amol} / \mathrm{ng}$ total RNA $(n=7 ; P<0.005$, unpaired $t$ test $)$, in control and acidosis, respectively. 
A

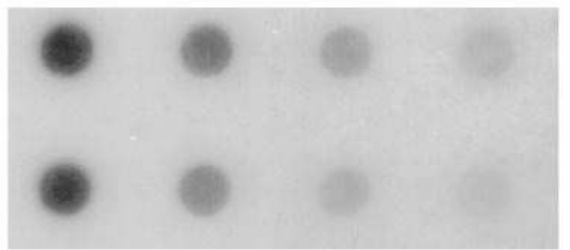

Acidosis

Control

B

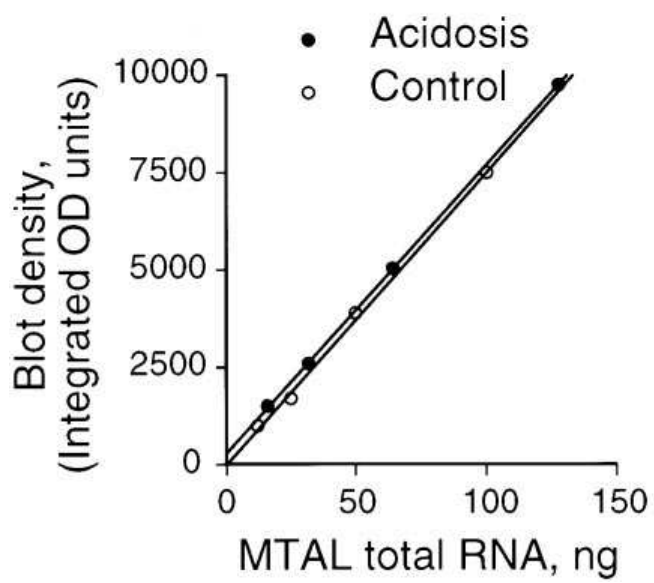

Figure 4. Dot-blot analysis of mRNAs during CMA. Serial twofold dilutions of MTAL total RNA were subjected to dot-blot analysis, hybridized with ${ }^{32} \mathrm{P}$-labeled oligo-dT as described in Methods. After a 2-h exposure, autoradiograms were scanned, and band densities were quantified. $(A)$ Representative autoradiograms of acidosis (top) and control groups (bottom). (B) Blot densities are plotted against the amount of total RNA loaded per lane, and data are fitted by linear analysis.

Effect of CMA on NHE-3 protein abundance. NHE-3 protein abundance was determined by Western blot analysis using a polyclonal anti-rat NHE-3 antibody. The specificity of this anti-NHE-3 antibody was previously demonstrated (9). As shown in Fig. 6, this antibody recognized an $\sim 87$-kD protein

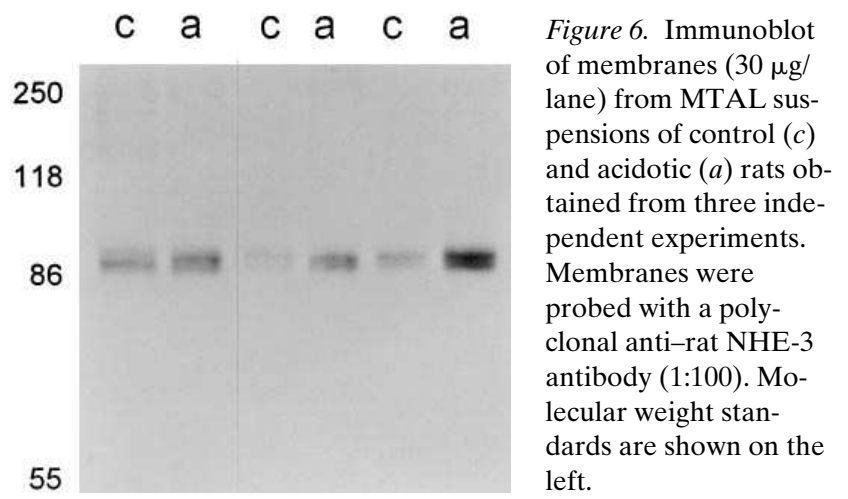

in membranes isolated from MTAL cells which corresponded to the NHE-3 protein, as previously described in the rat outer medulla (9). Furthermore, NHE-3 protein amount was enhanced during acidosis (Fig. 6). Results of eight experiments showed a mean $71 \pm 32 \%$ increase in NHE-3 protein abundance $(P<0.05)$ in rats fed with $\mathrm{NH}_{4} \mathrm{Cl}$ compared with control animals.

\section{Discussion}

Bicarbonate absorption by the rat MTAL displays chronic and acute regulation, suggesting that this segment has an important role in the physiological and pathophysiological control of acid-base balance (32-34). CMA is associated with an adaptive increase in the ability of the rat MTAL to absorb bicarbonate (14), and apical $\mathrm{Na}^{+} / \mathrm{H}^{+}$exchange has been shown to be responsible for bicarbonate absorption in MTALs from both control and acidotic rats (15). We have shown previously that, in the rat MTAL, NHE-1 and NHE-3 are expressed, but not NHE-2 and NHE-4 (18). Since NHE-3 is the apical Na $\mathrm{Na}^{+}$ exchanger of the rat MTAL $(9,20)$, the present experiments were designed to determine if CMA is associated with intrinsic adaptation of NHE-3, and which mechanisms are involved. Our results show that NHE-3 mRNA, protein abundance, and transport activity are increased in MTAL cells freshly isolated from chronically acidotic rats.

In the inner stripe of the outer medulla, NHE-3 is almost exclusively expressed in the TAL $(9,29)$. We then used a very sensitive competitive RT-PCR method which allowed us to de-
A

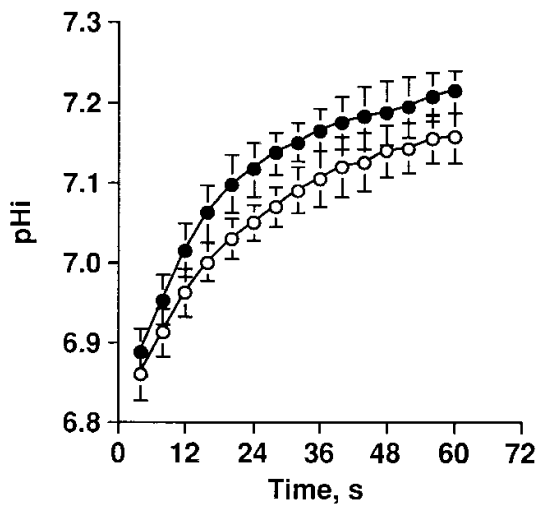

B

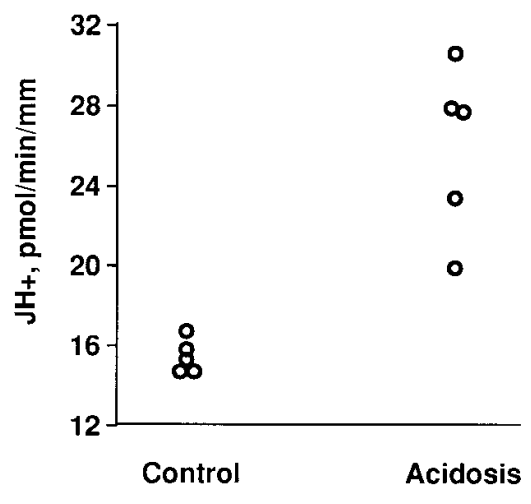

Figure 5. Effect of CMA on NHE-3 transport activity. $(A)$ Effect of CMA on sodium-dependent initial rates of $\mathrm{pHi}$ recovery (dpHi/dt). Na-depleted acidified MTAL cells were abruptly added into isosmotic $\mathrm{CO}_{2}$-free medium containing 30 $\mathrm{mM}$ Na. Points are means \pm SEM of five separate experiments in control (open circles) and acidosis (filled circles). (B) Effect of CMA on proton flux rates $\left(\mathrm{J}_{\mathrm{H}}^{+}\right) \cdot \mathrm{J}_{\mathrm{H}}^{+}$ was $15.4 \pm 0.4$ vs. $25.9 \pm 1.9 \mathrm{pmol} / \mathrm{min} / \mathrm{mm}$ ( $n=5 ; P<0.001$, unpaired $t$ test $)$, in control and acidosis, respectively. 
tect and quantify absolute amounts of NHE-3 mRNA from small amounts of total RNA extracted from MTAL cells. Our results clearly show a $69 \%$ increase in NHE-3 mRNA abundance during CMA. This increase is specific for NHE-3 mRNA since the abundance of mRNAs relative to total RNA, assayed by dot-blot analysis in the same suspensions of MTAL cells, is not modified by CMA.

The next step of this study was to determine if NHE-3 transport activity and NHE-3 protein abundance were also increased in MTAL cells during CMA. Since MTAL cells expressed only NHE-1, the amiloride-sensitive $\mathrm{Na}^{+} / \mathrm{H}^{+}$exchanger, and NHE-3 which is amiloride resistant, the use of HOE 694, a compound that completely blocks NHE-1 without altering NHE-3 at the concentration of $50 \mu \mathrm{M}(30,31)$, allowed us to study specifically NHE-3 transport activity. Our results demonstrate that CMA induced a mean $68 \%$ increase in NHE-3-mediated $\mathrm{J}_{\mathrm{H}}{ }^{+}$, which is of similar magnitude to that observed for $\mathrm{HCO}_{3}$ transport capacity in isolated, perfused MTALs of chronically acid-loaded rats (14). In the present study, NHE-3 protein abundance was assayed on MTAL membranes by immunoblot analysis using specific anti-NHE-3 antibodies which have been shown to specifically stain the luminal membrane of MTAL (9). Results showed that CMA also increased NHE-3 protein abundance by $71 \%$ in a membrane fraction obtained from MTAL tubules. This latter result is in agreement with recent results obtained by immunocytochemistry that show increased NHE-3 abundance in the TAL apical membranes of chronically acid-loaded rats (12).

Thus, this study demonstrates for the first time that in vivo CMA increases the level of mRNA transcript for NHE-3, which corresponds to quantitatively similar increases in NHE-3 protein abundance and transport activity in freshly isolated MTAL cells. These results thus strongly suggest that an increase in protein synthesis related to the increase in mRNA is responsible for the increase in NHE-3 transport activity we observed. In addition, these adaptations can explain the increase in $\mathrm{HCO}_{3}$ transport capacity observed in in vitro microperfused MTAL harvested from chronically acidotic rats (14).

Recent in vitro studies performed in cell lines derived from the proximal tubule have shown that acid incubation increases NHE-3 mRNA and EIPA-resistant $\mathrm{Na}^{+} / \mathrm{H}^{+}$antiporter activity in OKP cells (11), and NHE-3 protein abundance in LLC-PK cells (35). These results suggest that an increased protein synthesis is, at least in part, involved in these adaptations. In recent studies, CMA has been shown to increase NHE-3 protein abundance in brush border membrane vesicles isolated from $\mathrm{NH}_{4} \mathrm{Cl}$-treated rats $(12,13)$. However, cortical NHE-3 mRNA abundance assayed by Northern blot analysis was not significantly modified by acidosis (12). One possible explanation for this absence of significant effect of acidosis on cortical NHE-3 mRNA could be the difference of sensitivity of the methods used, Northern blot versus quantitative RT-PCR. Although, in this study, increases in mRNA transcript for NHE-3 and in protein synthesis seem to be the main mechanism for antiporter activation, other additional mechanisms such as a decrease in protein degradation, exocytic insertion, or activation of an inactive subpopulation of transporters cannot be excluded.

The mediators of these adaptations of NHE-3 during CMA have not been identified in these experiments. In this study, CMA led to a $50 \%$ increase in cell volume in agreement with epithelial cell hypertrophy described previously (36). It should be noted that in vitro acid incubation, which does not induce cell hypertrophy (37), increases NHE-3 mRNA abundance in OKP cells (11), suggesting that these adaptations can occur in the absence of cell hypertrophy. Furthermore, in vitro studies on OKP cells have shown that herbimycin A, a tyrosine kinase inhibitor, and csk overexpression, which inactivate the c-src nonreceptor protein tyrosine kinase, prevented the acid activation of the apical $\mathrm{Na}^{+} / \mathrm{H}^{+}$exchanger (38). These data suggest that, in OKP cells, the c-src nonreceptor protein tyrosine kinase plays a key role in acid activation of NHE-3. Whether such mechanisms are involved in NHE-3 adaptation in the rat MTAL remains to be determined. At present, it is not known whether the increased NHE-3 mRNA abundance observed in our study results from increased transcription of the NHE-3 gene and/or decreased transcript degradation. Indeed, in vitro studies in LLC-PK 1 cells have shown that both mechanisms could be involved in the acid-induced increase in mRNA abundance of glutaminase (decreased mRNA degradation) (39) and phosphoenolpyruvate carboxykinase (increased transcription) (40), two enzymes that contribute to renal acidification by increasing ammonia synthesis.

Acidosis-induced NHE-3 activation, by enhancing transcellular $\mathrm{H}^{+}$secretion in the TAL, could contribute to the decreased luminal $\mathrm{HCO}_{3}^{-}$concentration observed in the distal tubule (41). This process seems particularly important since the increased $\mathrm{NH}_{4}^{+}$absorption by the MTAL during CMA, by generating luminal $\mathrm{HCO}_{3}^{-}$(14), is susceptible to increase luminal $\mathrm{HCO}_{3}^{-}$amounts in the loop of Henle during acidosis.

In summary, this study demonstrates that NHE-3 adapts to CMA in the rat MTAL. This adaptation involved an increase in mRNA transcript that can explain the increased NHE-3 protein abundance and activity.

\section{Acknowledgments}

This study was supported by grants from the Institut National de la Santé et de la Recherche Médicale and the Université Paris 6 and from the National Institutes of Health (DK-39298).

\section{References}

1. Kunau, R.T.J., J.I. Hart, and K.A. Walker. 1985. Effect of metabolic acidosis on proximal tubular total $\mathrm{CO}_{2}$ absorption. Am. J. Physiol. 249:F62-F68.

2. Akiba, T., V.K. Rocco, and D.G. Warnock. 1987. Parallel adaptation of the rabbit renal cortical sodium/proton antiporter and sodium/bicarbonate cotransporter in metabolic acidosis and alkalosis. J. Clin. Invest. 80:308-315.

3. Preisig, P.A., and R.J. Alpern. 1988. Chronic metabolic acidosis causes an adaptation in the apical membrane $\mathrm{Na} / \mathrm{H}$ antiporter and basolateral membrane $\mathrm{Na}\left(\mathrm{HCO}_{3}\right)_{3}$ symporter in the rat proximal convoluted tubule. J. Clin. Invest. 82: 1445-1453.

4. Kinsella, J., T. Cujdik, and B. Sacktor. 1984. $\mathrm{Na}^{+}-\mathrm{H}^{+}$exchange in isolated renal brush-border membrane vesicles in response to metabolic acidosis. Kinetics effects. J. Biol. Chem. 259:13224-13227.

5. Tsai, C.J., H.E. Ives, R.J. Alpern, V.J. Yee, D.G. Warnock, and F.C. Rector, Jr. 1984. Increased $\mathrm{V}_{\max }$ for $\mathrm{Na}^{+} / \mathrm{H}^{+}$antiporter activity in proximal tubule brush border vesicles from rabbits with metabolic acidosis. Am. J. Physiol. 247: F339-F343.

6. Cohn, D.E., S. Klahr, and M.R. Hammerman. 1983. Metabolic acidosis and parathyroidectomy increase $\mathrm{Na}^{+}-\mathrm{H}^{+}$exchange in brush border vesicles. Am. J. Physiol. 245:F217-F222.

7. Chambrey, R., M. Paillard, and R.A. Podevin. 1994. Enzymatic and functional evidence for adaptation of the vacuolar H-ATPase in proximal tubule apical membranes from rats with chronic metabolic acidosis. J. Biol. Chem. 269: 3243-3250.

8. Biemesderfer, D., J. Pizzonia, A. Abu-Alfa, M. Exner, R. Reilly, P. Igarashi, and P.S. Aronson. 1993. NHE3: a Na${ }^{+} / \mathrm{H}^{+}$exchanger isoform of renal brush border. Am. J. Physiol. 265:F736-F742.

9. Amemiya, M., J. Loffing, M. Lötscher, B. Kaissling, R.J. Alpern, and O.W. Moe. 1995. Expression of NHE-3 in the apical membrane of rat renal 
proximal tubule and thick ascending limb. Kidney Int. 48:1206-1215.

10. Alpern, R.J., O.W. Moe, and P.A. Preisig. 1995. Chronic regulation of the proximal tubular $\mathrm{Na} / \mathrm{H}$ antiporter: from $\mathrm{HCO}_{3}$ to $S R C$. Kidney Int. 48:13861396.

11. Amemiya, M., Y. Yamaji, A. Cano, O.W. Moe, and R.J. Alpern. 1995. Acid incubation increases NHE-3 mRNA abundance in OKP cells. Am. J. Physiol. 269:C126-C133.

12. Ambühl, P.M., M. Amemiya, M. Lötscher, M. Danczkay, B. Kaissling, P.A. Preisig, O.W. Moe, and R.J. Alpern. 1995. Chronic metabolic acidosis increases NHE-3 protein abundance. JASN (J. Am. Soc. Nephrol.). 6:303.

13. Wu, M.H., D. Biesmesderfer, G. Giebish, and P.S. Aronson. 1995. Role of NHE3 in mediating renal brush border Na-H exchange: adaptation to acidosis. JASN (J. Am. Soc. Nephrol.). 6:318.

14. Good, D.W. 1990. Adaptation of $\mathrm{HCO}_{3}^{-}$and $\mathrm{NH}_{4}{ }^{+}$transport in rat MTAL: effects of chronic metabolic acidosis and $\mathrm{Na}^{+}$intake. Am. J. Physiol. 258:F1345-F1353.

15. Good, D.W., and B.A. Watts. 1996. Functional roles of apical membrane $\mathrm{Na}^{+} / \mathrm{H}^{+}$exchange in rat medullary thick ascending limb. Am. J. Physiol. 270:F691-F699.

16. Watts, B.A., and D.W. Good. 1994. Apical membrane $\mathrm{Na}^{+} / \mathrm{H}^{+}$exchange in rat medullary thick ascending limb. pHi dependence and inhibition by hyperosmolality. J. Biol. Chem. 269:20250-20255.

17. Froissart, M., P. Borensztein, P. Houillier, F. Leviel, J. Poggioli, E. Marty, M. Bichara, and M. Paillard. 1992. Plasma membrane $\mathrm{Na}^{+}-\mathrm{H}^{+}$antiporter and $\mathrm{H}^{+}$-ATPase in the medullary thick ascending limb of rat kidney. Am. J. Physiol. 262:C963-C970.

18. Borensztein, P., M. Froissart, K. Laghmani, M. Bichara, and M. Paillard. 1995. RT-PCR analysis of $\mathrm{Na}^{+} / \mathrm{H}^{+}$exchanger mRNAs in rat medullary thick ascending limb. Am. J. Physiol. 268:F1224-F1228.

19. Biemesderfer, D., R.F. Reilly, M. Exner, P. Igarashi, and P.S. Aronson. 1992. Immunocytochemical characterization of $\mathrm{Na}^{+} / \mathrm{H}^{+}$exchanger isoform NHE-1 in rabbit kidney. Am. J. Physiol. 263:F833-F840.

20. Attmane-Elakeb, A., R. Chambrey, M. Tsimaratos, F. Leviel, A. Blanchard, D.G. Warnock, M. Paillard, and R.A. Podevin. 1996. Isolation and characterization of luminal and basolateral plasma membrane vesicles from the medullary thick ascending loop of Henle: polarized expression of different $\mathrm{Na}^{+} / \mathrm{H}^{+}$exchangers. Kidney Int. 50:1051-1057.

21. Soleimani, M., C. Bookstein, G.L. Bizal, M.W. Musch, Y.J. Hattabaugh, M.C. Rao, and E.B. Chang. 1994. Localization of the $\mathrm{Na}^{+} / \mathrm{H}^{+}$exchanger isoform NHE-3 in rabbit and canine kidney. Biochim. Biophys. Acta. 1195:89-95.

22. Trinh-Trang-Tan, M.M., N. Bouby, C. Coutaud, and L. Bankir. 1986. Quick isolation of rat medullary thick ascending limbs. Enzymatic and metabolic characterization. Pflügers Arch. 407:228-234.

23. Amlal, H., M. Paillard, and M. Bichara. 1994. $\mathrm{NH}_{4}{ }^{+}$transport pathways in cells of medullary thick ascending limb of rat kidney. $\mathrm{NH}_{4}{ }^{+}$conductance and $\mathrm{K}^{+} / \mathrm{NH}_{4}{ }^{+}\left(\mathrm{H}^{+}\right)$antiport. J. Biol. Chem. 269:21962-21971. 434.

24. Roos, A., and W.F. Boron. 1981. Intracellular pH. Physiol. Rev. 61:296-

25. Sudo, J., and F. Morel. 1984. $\mathrm{Na}^{+}$and $\mathrm{K}^{+}$cell concentrations in collagenase-treated rat kidney tubules incubated at various temperatures. Am. J. Physiol. 246:C407-C414.
26. Amlal, H., C. LeGoff, C. Vernimmen, M. Paillard, and M. Bichara. 1996. $\mathrm{Na}^{+}-\mathrm{K}^{+}\left(\mathrm{NH}_{4}^{+}\right)-2 \mathrm{Cl}^{-}$cotransport in medullary thick ascending limb. Control by PKA, PKC, and 20-HETE. Am. J. Physiol. 271:C455-C463.

27. Chomczynski, P., and N. Sacchi. 1987. Single step method of RNA isolation by acid guanidinium thiocyanate-phenol-chloroform extraction. Anal. Biochem. 162:156-159.

28. Wang, Z., J. Orlowski, and G.E. Shull. 1993. Primary structure and functional expression of a novel gastrointestinal isoform of the rat $\mathrm{Na} / \mathrm{H}$ exchanger. J. Biol. Chem. 268:11925-11928.

29. Borensztein, P., K. Laghmani, M. Froissart, M. Philippe, M. Bichara, and M. Paillard. 1994. RT-PCR analysis of $\mathrm{Na} / \mathrm{H}$ exchanger isoforms mRNAs in the rat outer medulla. Adaptation to in vivo chronic metabolic acidosis. JASN (J. Am. Soc. Nephrol.). 5:248.

30. Counillon, L., W. Scholz, H.J. Lang, and J. Pouyssegur. 1993. Pharmacological characterization of stably transfected $\mathrm{Na}^{+} / \mathrm{H}^{+}$antiporter isoforms using amiloride analogs and a new inhibitor exhibiting anti-ischemic properties. Mol. Pharmacol. 44:1041-1045.

31. Bichara, M., H. Amlal, K. Laghmani, P. Borensztein, and M. Paillard. 1995. Control of NHE-3 transport activity by PKA, PKC, and arachidonic acid in MTAL cells. JASN (J. Am. Soc. Nephrol.). 6:332.

32. Capasso, G., R. Unwin, F. Ciani, N.G. De Santo, G. De Tommaso, F. Rosso, and G. Giebisch. 1994. Bicarbonate transport along the loop of Henle. II. Effects of acid-base, dietary, and neurohumoral determinants. J. Clin. Invest. 94:830-838.

33. Good, D.W. 1993. The thick ascending limb as a site of renal bicarbonate reabsorption. Semin. Nephrol. 13:225-235.

34. Paillard, M., and M. Bichara. 1989. Peptide hormones effects on urinary acidification and acid-base balance: PTH, ADH, and glucagon. Am. J. Physiol. 256:F973-F985.

35. Soleimani, M., C. Bookstein, J.A. McAteer, Y.J. Hattabaugh, G.L. Bizal, M.W. Musch, M. Villereal, M.C. Rao, R.L. Howard, and E.B. Chang. 1994 Effect of high osmolality on $\mathrm{Na}^{+} / \mathrm{H}^{+}$exchange in renal proximal tubule cells. $J$. Biol. Chem. 269:15613-15618.

36. Lotspeich, W.D. 1965. Renal hypertrophy in metabolic acidosis and its relation to ammonia excretion. Am. J. Physiol. 208:1138-1142.

37. Jurkovitz, C.T., B.K. England, R.G. Ebb, and W.E. Mitch. 1992. Influence of ammonia and $\mathrm{pH}$ on protein and amino acid metabolism in LLC-PK1 cells. Kidney Int. 42:595-601.

38. Yamaji, Y., M. Amemyia, A. Cano, P.A. Preisig, R.T. Miller, O.W. Moe, and R.J. Alpern. 1995. Overexpression of csk inhibits acid-induced activation of NHE-3. Proc. Natl. Acad. Sci. USA. 92:6274-6278.

39. Hansen, W.R., N. Barsic-Tress, L. Taylor, and N.P. Curthoys. 1996. The 3 '-nontranslated region of rat renal glutaminase mRNA contains a pH-responsive stability element. Am. J. Physiol. 271:F126-F131.

40. Holcomb, T., W. Liu, R. Snyder, R. Shapiro, and N.P. Curthoys. 1996. Promoter elements that mediate the $\mathrm{pH}$ response of PCK mRNA in LLC$\mathrm{PK}_{1}-\mathrm{F}^{+}$cells. Am. J. Physiol. 271:F340-F346.

41. Buerkert, J., D. Martin, and D. Trigg. 1983. Segmental analysis of the renal tubule in buffer production and net acid formation. Am. J. Physiol. 244: F442-F454. 